\section{$\underset{\substack{\text { hommes } \\ \text { \& migrations }}}{ }$}

\section{Hommes \& migrations}

Revue française de référence sur les dynamiques

migratoires

\section{$1295 \mid 2012$}

Algérie - France : une communauté de destin

\title{
Sur la planche
}

Film marocain de Leilla Kilani

\section{André Videau}

\section{Q OpenEdition \\ 1 Journals}

Édition électronique

URL : http://journals.openedition.org/hommesmigrations/1093

DOI : 10.4000/hommesmigrations.1093

ISSN : 2262-3353

Éditeur

Musée national de l'histoire de l'immigration

Édition imprimée

Date de publication : 1 janvier 2012

Pagination : 176

ISSN : 1142-852X

\section{Référence électronique}

André Videau, «Sur la planche », Hommes \& migrations [En ligne], 1295 | 2012, mis en ligne le 29 mai 2013, consulté le 22 septembre 2020. URL : http://journals.openedition.org/hommesmigrations/1093 ; DOI : https://doi.org/10.4000/hommesmigrations.1093

Ce document a été généré automatiquement le 22 septembre 2020.

Tous droits réservés 


\title{
Sur la planche
}

\author{
Film marocain de Leïla Kilani
}

\section{André Videau}

Elles s'appellent Badia, Imane, Asma, Nawal... (Soufia Issami, Mouna Bahmad, Nouzha Akel, Sara Betioui). Elles ont, plus ou moins, une vingtaine d'années. Leur langage précipité et provocant est un mélange du parler des rues et du bled, d'arabe et de verlan, de français, d'espagnol, de rifain. Elles proviennent des quatre coins du Maroc miséreux en quête de travail, de dirhams et de liberté. Elles ont rejoint la rutilante zone franche de Tanger, foyer de la jeune industrialisation marocaine et territoire affecté aux délocalisations. Elles vont y grossir l'inépuisable réservoir de main-d'œuvre féminine.

2 Sans formation, ni instruction, ni compétences, ni piston, elles ne peuvent être embauchées dans l'aristocratie du textile plus lucrative. Elles intègrent le sousprolétariat chargé du conditionnement des crustacés. On pourrait les appeler "les mômes crevettes", tellement l'odeur des bestioles manipulées à longueur de journée s'incruste à la racine des ongles et des cheveux et résiste à tous les brossages, à tous les contre-parfums. "Petites bricoleuses de l'urgence et de l'espace", elles sont soumises à la rigueur des horaires et des cadences mais peuvent abuser de leur jeunesse et de leurs insomnies. Elles ne sont jamais au bout de leurs peines ni des opportunités. On les dit “ t'debarrates", affranchies, insoumises. Ceux qui ont misé sur leur passivité ont perdu. Belles et rebelles comme des héroïnes de Genet ou de Mohamed Choukri dont les souvenirs subversifs hantent la région. Le slam rageur de l'une d'elles donne le ton :

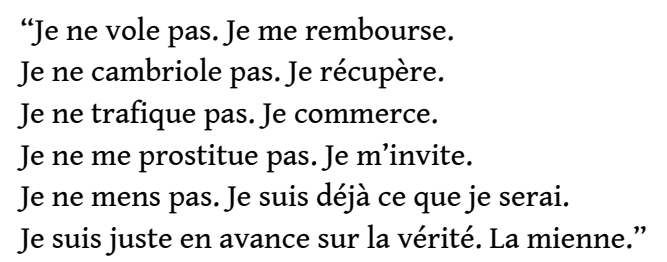

3 En les suivant nuit et jour de leur poste de travail à leurs escapades, de leur logement rudimentaire à leur transport sous surveillance comme des convois concentrationnaires, de leur nourriture calibrée à leurs libations clandestines, de leurs débordements de conduite mélangeant sexe et larcin, Leïla Kilani réalise un 
documentaire agressif qui éclaire d'un jour cru les phénomènes d'industrialisation sauvage dans les économies en développement. Une pièce au dossier qui vaut tous les discours. 